\title{
A HILIC Stationary Phase Functionalized with Glutathione by Thiol-Ene Chemistry on Monodisperse-Porous Polymer Microparticles
}

\section{Monodispers-Gözenekli Polimer Mikropartiküller Üzerinde Tiyol-En Kimyası Kullanılarak Glutatyon ile Fonksiyonelleştirilmiş HILIC Sabit Fazı}

\section{Çiğdem Kip}

Hacettepe University, Chemical Engineering Department, Ankara, Turkey.

\section{A B STRACT}

$\mathrm{M}$ onodisperse-porous microparticles functionalized with glutathione by thiol-ene chemistry were synthesized as a new stationary phase for hydrophilic interaction chromatography. Monodisperse-porous poly(3-trimethoxysilylpropyl methacrylate-co-ethylene dimethacrylate), poly(TMSPM-co-EDMA) microspheres (6 $\mu$ m in size) were obtained with different seed latex/monomer ratios and diluent compositions by multistage microsuspension copolymerization. The zwitterionic chromatographic ligand containing thiol moiety (i.e. glutathione) were covalently attached onto the TMSPM attachedpoly(TMSPM-co-EDMA) microparticles. The selected starting material allowed the direct attachment of zwitterionic ligand onto the support material using thiol-ene chemistry. The derivatized microparticles were slurry packed into the microbore columns with $2 \mathrm{~mm}$ i.d. and used as stationary phase for the separation of nucleosides in hydrophilic interaction chromatography with the plate numbers up to 54.000 plates $/ \mathrm{m}$. The results showed the usability of tailored poly (TMSPM-co-EDMA) microparticles as a stationary phase and thiol-ene chemistry in the manufacture of a chromatographic stationary phase with high efficiency in hydrophilic liquid chromatography applications.

\section{Key Words}

Thiol-ene chemistry, Monodisperse-porous microparticles, Hydrophilic interaction chromatography, nucleosides.

\section{öz}

\footnotetext{
Tiyol-en kimyası kullanılarak glutatyon ile fonksiyonelleştirilmiş eşboyutlu-gözenekli mikropartiküller, hidrofilik etkileşim kromatografisi için yeni bir sabit faz olarak sentezlenmiştir. Monodispers-gözenekli poli (3-trimetoksisililpropilmetakrilatco-etilendimetakrilat), poli(TMSPM-co-EDMA) mikropartiküller (boyut olarak 6 mikron), farklı çıkış lateksi/monomer ve diluent bileşimleri ile çok basamaklı mikrosüspansiyon kopolimerizasyonu ile elde edilmiştir. Tiyol ucu içeren zwitterionik kromatografik ligand (glutatyon), TMSPM bağlı poli (TMSPM-co-EDMA) mikropartiküller üzerine kovalent olarak bağlanmıştır. Seçilen başlangıç materyali, zwitteriyonik kromatografik ligandın, tiyolen kimyası kullanılarak destek materyali üzerine doğrudan bağlanmasına olanak sağlamıştır. Türevlendirilmiş mikropartiküller, $2 \mathrm{~mm}$ iç çapa sahip mikrobor kolonlar içerisine dolgulanmış ve hidrofilik etkileşim kromatografisinde 54000 plaka/m plaka sayısı ile nükleositlerin ayrılması için sabit faz olarak kullanılmıştır. Sonuçlar, yüksek verimlilikle hidrofilik sıvı kromatografisi uygulamaları için kromatografik sabit fazın üretiminde poli(TMSPM-co-EDMA) mikropartiküllerin ve tiyol-en kimyasının kullanılabileceğini göstermiştir.
}

\section{Anahtar Kelimeler}

Tiyol-en kimyası, eşboyutlu-gözenekli mikropartiküller, hidrofilik etkileşim kromatografisi, nükleositler.

Article History: Received: May 17, 2019; Revised: Sep 20, 2019; Accepted: Oct 15, 2019; Available Online: Jan 1, 2020 DOI: https://doi.org/10.15671/ hjbc.567057 


\section{INTRODUCTION}

L igh Performance Liquid Chromatography (HPLC) Is a highly sensitive method commonly used in chromatographic separation techniques for the qualitative and quantitative analysis of a liquid phase soluble mixture. The most important features of HPLC which provide great success are reproducibility, high purification capability and ease of modification in the chromatographic method. From 1990 onwards, hydrophilic interaction chromatography (HILIC) is a new liquid chromatographic technique that is rapidly evolving in recent years and is particularly an alternative to reverse phase liquid chromatography (RPLC) [1]. This technique is rapidly becoming popular in the analysis of polar analytes especially neurotransmitters, nucleosides, oligosaccharides, peptides [2-7]. This method eliminates the disadvantages such as poor solubility seen in NPLC and poor retention of polar compounds seen in $\operatorname{RPLC}[8,9]$.

Nucleosides and nucleotides, which are highly hydrophilic, are important compounds in metabolic processes and their chromatographic separations are extremely important because of their similar and complex structures [10-12]. In HILIC, silica or silica functionalized with various polar groups are commonly used as packing materials for separation of these compounds [9]. The wide range of structural variations of HILIC-type stationary phases has led researchers to study the development of new HILIC stationary phases with high separation efficiency. Recently, thiol-ene chemistry has been particularly applied for the synthesis of hybrid stationary phases for different chromatographic applications [13-18]. Thiol-ene chemistry, which has superior properties over alkyne-azide click chemistry due to its properties such as metal-free catalysis, high reaction yield and simple usage has enabled this technique to be widely applied in the field of biology and organic chemistry [19]. Glutathione, one of the natural zwitterionic compounds, has high hydrophilicity and multi-biolytic activity due to its structure consisting of glutamic acid, cysteine and glycerin $[20,21]$. Glutathione also contains thiol group and it can be immobilized by "thiol-ene" click chemistry on support containing both silica and polymeric constituents $[21,22]$.

The studies demonstrated that "thiol-ene" click chemistry could be effectively utilized both for the synthe- sis of stationary phases and the covalent attachment of chromatographic ligands onto the stationary phases. For example, Qiao et al. developed imidazolium-based zwitterionic stationary phases for specific capture of nucleosides, nucleic acid bases, benzoic acids [23]. Peng et al. prepared a carboxyl-bonded silica stationary phase via "thiol-ene" click chemistry. The resulting column demonstrated excellent high efficiency for the separation of nucleosides and bases [24]. A HILIC/ cation-exchange stationary phase showing a HILIC separation of nucleosides and nucleobases was obtained via thiol-ene click polymerization reaction of $\mathrm{N}, \mathrm{N}^{\prime}$ methylenebisacrylamide (MBAAm) and 3- allyloxy-2hydroxy-1-propanesulfonic acid sodium salt (AHPS) [17]. Ren et al. prepared stationary phase using two kinds of monomers by thiol-ene click chemistry and used this column in hydrophilic interaction mode to separate nucleosides and nucleobases [25]. Yang et al. reported a novel stationary phase synthesized by thiol-ene "click" chemistry for hydrophilic interaction liquid chromatography. Compared to the traditional silica stationary phases, the novel stationary phase exhibits good separation ability for uridine and bases [26].

In this study, thiol-ene chemistry was used to attach the chromatographic ligand onto the particle-based chromatographic stationary phases. An organosilane based polymeric support (poly(TMSPM-co-EDMA) was first tailored with its functional monomer (TMSPM) and glutathione as a chromatographic ligand was covalently attached onto the acrylate moiety of monomeric constituent bound onto the polymeric matrix via thiol-ene chemistry. Firstly, monodisperse porous poly (3-trimethoxysilylpropyl methacrylate-co-ethylene dimethacrylate), poly(TMSPM-co-EDMA) microspheres were synthesized in 6 micron size. The polymerization conditions (monomer/seed latex ratio and diluent composition) were changed to investigate the effect of polymerization conditions on the size and porous properties of the particles. TMSPM was then covalently attached to the poly(TMSPM-co-EDMA) microspheres by via silanization. Glutathione selected as the chromatographic ligand was then immobilized onto the TMSPM attached poly TMSPM-co-EDMA) microspheres. Uracil, adenine, inosine and cytidine were separated on the column to evaluate the column performance in hydrophilic interaction mode. 


\section{MATERIALS and METHODS}

\section{Materials}

The monomers, 3-trimethoxysilylpropyl methacrylate (TMSPM), glycidyl methacrylate (GMA), and the crosslinking agent, ethylene dimethacrylate (EDMA) were obtained from Aldrich Chem. Co., (St. Louis, MO, USA). Ethylbenzene (EB), cyclohexanol (Cyc-OH) and dibutylphtalate (DBP) used as diluent, and ethanol (EtOH) and tetrahydrofuran (THF, HPLC grade) used as solvents, were also supplied from Aldrich. 2,2'-azobisisobutyronitrile (AIBN) used as initiator was obtained from Across Organics, England and recrystallized from methanol before use. Benzoyl peroxide (BPO) obtained from Merck A.G., Darmstadt, Germany was dried in vacuo at $35{ }^{\circ} \mathrm{C}$ before use. Polyvinylalcohol (PVA, 87-89 \% hydrolyzed, molecular weight: 85,000-146,000 Da), polyvinylpyrrolidone (PVP K-30, molecular weight: 40000 Da) and sodium lauryl sulfate (SLS) were supplied from Sigma. The hydrophilic ligand, glutathione (GSH) were also obtained from Sigma. The analytes, uracil, adenine, inosine and cytidine were purchased from Sigma (St. Louis, MO, USA). Acetonitrile (ACN, HPLC grade) supplied from Sigma (St. Louis, MO, USA) and deionized water (Milli-Q system, Millipore Inc., Milford,MA) were used for the preparation of mobile phase.

\section{Synthesis and Characterization of poly(TMSPM-co- EDMA) Microparticles}

In the first step for the production of the polymeric material in the form of monodisperse-macroporous particles to be used as the stationary phase, poly(glycidyl methacrylate), [poly(GMA)] seed latex was synthesized by the dispersion polymerization method [27-30]. The monodisperse-porous particles were then obtained by the multistep microsuspension polymerization method [31]. In this method, the seed latex was swollen with a low molecular weight organic agent mixture (cyclohexanol $(\mathrm{CycOH})$ / dibutylphthalate (DBP) and the monomer phase containing monomer (TMSPM), crosslinker (EDMA) and initiator (BPO).

Typically, [poly(GMA)] seed latex was firstly added into emulsion containing the porogen system ( $\mathrm{Cyc}-\mathrm{OH} / \mathrm{DBP}$ ) in the presence of SLS as the emulsifier and the resulting emulsion was stirred at room temperature for 20 h. The monomer phase containing TMSPM, EDMA and BPO was dispersed in the aqueous phase containing SLS and stirred for 24 hours in the magnetic stirrer. In the last step, PVA was added as a stabilizer to the swollen particles and the polymerization was carried out in a shaking water bath at $800 \mathrm{C}$ for 20 hours. At the end of the polymerization, monodisperse particles were precipitated by centrifuging at approximately $2000 \mathrm{rpm}$ for about 3 minutes to remove monodisperse-macroporous particles from the polymerization medium. Centrifugation-decantation process was completed by washing the particles with ethanol, THF, ethanol, distilled water 2 times.

Scanning Electron Microscope (SEM) (JEOL, JEM 1200 EX, Japan) was used to determine the particle size, the size distribution and the particle surface morphology. For SEM photographs, dried monodisperse porous particles were coated by a thin layer of gold under vacuum. Si contents of particles were determined by EDX analysis. The mean particle diameters and standard deviation values used to determine the monodispersity of particles are calculated by Equations 1 and 2, respectively. The coefficient of variation (CV) values are calculated by the formula given in Equation 3.

$$
\begin{array}{lr}
\mathrm{D}_{\mathrm{n}}=\sum N i D i / \sum N i & \text { Eqn 1 } \\
\mathrm{SD}=\sqrt{\sum N i(D i-D n)^{2} /\left(\sum(N i-1)\right.} & \text { Eqn 2 } \\
\% \mathrm{C}_{\mathrm{V}}=\mathrm{SD} / \mathrm{D}_{\mathrm{n}} & \text { Eqn 3 }
\end{array}
$$

where $D_{n}$, Average particle size; $C V$, coefficient of variation for size distribution; SD, standard deviation; Ni, number of particles.

The surface area of the particles was determined by Quantochrome, Nova 2200e model Surface Area and Pore Size Meter (BET). First, the particles were dried at $70^{\circ} \mathrm{C}$ for 24 hours. The particles in the glass cells were subjected to vacuum at $80^{\circ} \mathrm{C}$ for 6 hours. The measurement of porous properties was then carried out in the sample cells placed in liquid nitrogen. The principle of measurement is based on the adsorption of nitrogen gas passed onto the particles and calculating the adsorbed amount from the vapor pressure of the nitrogen. The analyses were performed with approximately $0.1 \mathrm{~g}$ of each sample and the measurements were carried out with 2 samples being made independently and simultaneously. 


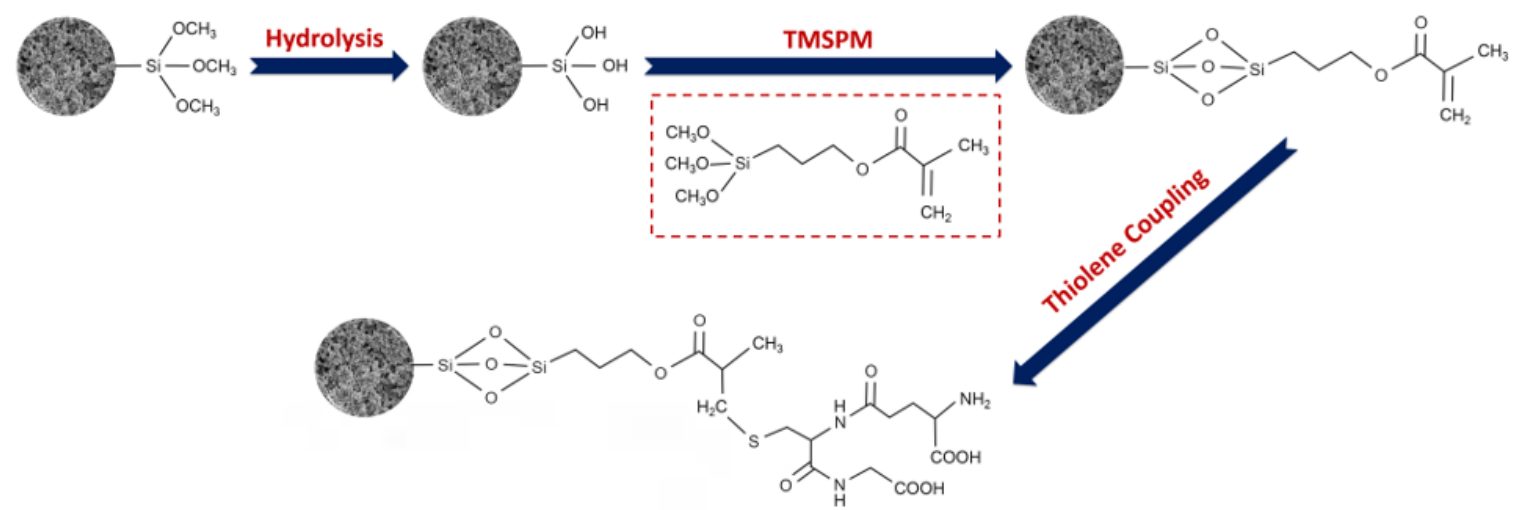

Figure 1. The chemical reaction route for the attachment of TMSPM and the hydrophilic ligand onto the poly (TMSPM-CO-EDMA) microparticles.

\section{Surface modification of poly(TMSPM-co-EDMA) microparticles with zwitterionic hydrophilic ligand}

TMSPM was covalently attached to the monodisperse-porous poly(TMSPM-co-EDMA) particles via the silanization reaction with the hydroxyl groups formed by hydrolysis of the alkoxysilanes on the particles. The hydrophilic ligand (glutathione) containing the thiol group was then covalently attached to the structure via thiol-ene reaction. The chemical reaction route for the attachment of TMSPM and the hydrophilic ligand onto the poly (TMSPM-Co-EDMA) particles are given in Figure 1.

Firstly, a mixture was prepared by mixing TMSPM $(5 \mathrm{~mL})$, Iso-PrOH $(25 \mathrm{~mL})$ and TEA $(0.75 \mathrm{~mL})$. Then, $0.5 \mathrm{~g}$ of poly (TMSPM-CO-EDMA) particles were added into the mixture and then sonicated for $2 \mathrm{~min}$. The attachment of TMSPM to poly(TMSPM-co-EDMA) microparticles was carried out at $60^{\circ} \mathrm{C}$ for 8 hours. Then $250 \mathrm{mg}$ of GSH and $1 \mathrm{wt} \%$ AIBN were dissolved in ethanol/water mixture and TMSPM@poly (TMSPM-co-EDMA) microparticles were added into mixture. The reaction was carried out at $70^{\circ} \mathrm{C}$ for $20 \mathrm{~h}$.

\section{Chromatography}

GSH attached TMSPM@poly (TMSPM-co-EDMA) microparticles were slurry packed into the stainless steel column of $30 \mathrm{~cm}$ length with a column diameter of $2 \mathrm{~mm}$. Distilled water was passed through the column at a flow rate of $5 \mathrm{~mL} / \mathrm{min}$ for 30 minutes to allow the particles to be packed in the column by using an HPLC pump (Shimadzu, LC-10 ADVP, Japan). The relationship of the back-pressure and flow rate for the column was deter- mined in isocratic mode using a solution of acetonitrile / water $(93 / 7 \mathrm{~mL} / \mathrm{mL})$ as the mobile phase. The mobile phase flow rate was changed between $0.1-1.0 \mathrm{~mL} / \mathrm{min}$ and the back pressure values of the column were recorded at each flow rate. The column was conditioned at a flow rate of $0.5 \mathrm{~mL} / \mathrm{min}$ for 2 hours with the mobile phase to be used in the HILIC study.

In HILIC experiments, a sample mixture containing polar analytes was used. The chromatographic separations were performed in the isocratic mode with the appropriate mobile phase (ACN/water) ratio. Injection of the analyte mixture was performed manually, using a 20 $\mu \mathrm{L}$ injection cycle. The chromatographic separations of nucleosides were performed in High Pressure Liquid Chromatography system (HPLC, Shimadzu, Japan).

The retention factor, $k$, for the analytes was calculated according to Eqn 4
$k=\left(t_{R}-t_{0}\right) / t_{0}$
Eqn 4

where $t_{R}$ is the retention time of the analytes; $t_{0}$ is the retention time of the void marker.

\section{RESULTS and DISCUSSION}

\section{Characterization}

In the microsuspension polymerization, seed latex/monomer and $\mathrm{CyCOH} / \mathrm{DBP}$ ratios were changed to obtain particles having different mean size and porosity characteristics.

The SEM photographs showing size distribution and surface morphology of monodisperse porous poly(TMSPM-Co-EDMA) microparticles synthesized by 

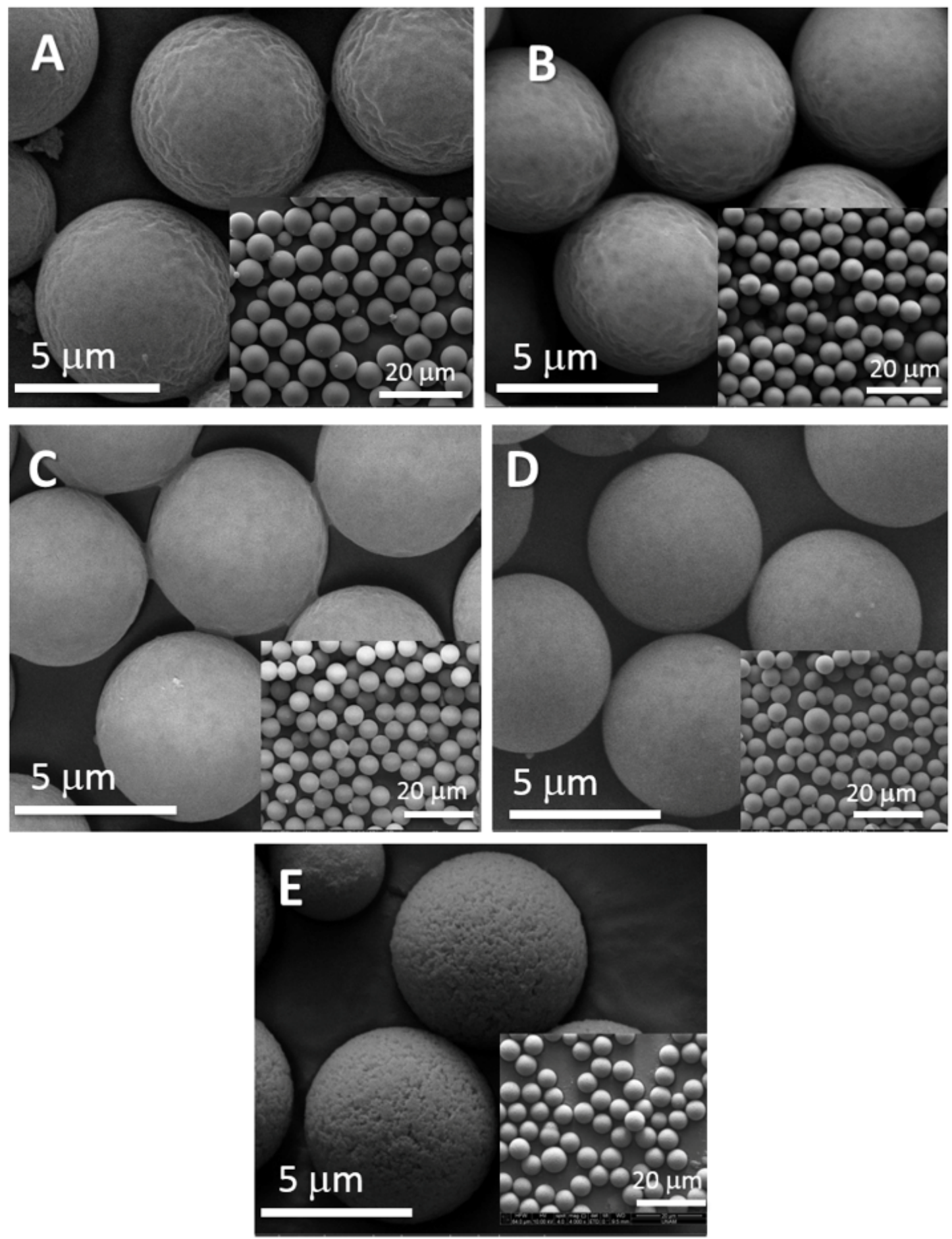

Figure 2. The SEM photographs showing size distribution and surface morphology of monodisperse porous poly(TMSPM-CO-EDMA) microparticles synthesized with different seed latex/monomer ratio A) 0.028 , B) 0.038 , C) 0.048 , D) 0.058 , E) 0.078 . 
Table 1. The properties of poly(TMSPM-Co-EDMA) particles synthesized with various seed latex / monomer ratio.

\begin{tabular}{|c|c|c|c|c|}
\hline $\mathrm{SL} / \mathrm{M}(\mathrm{g} / \mathrm{mL})$ & $\mathrm{Dp}(\mu \mathrm{m})$ & CV (\%) & $\mathrm{SSA}\left(\mathrm{m}^{2} / \mathrm{g}\right)$ & Si content (\%wt) \\
\hline 0.028 & 6.36 & 3.90 & 70 & 3.05 \\
\hline 0.038 & 5.86 & 3.10 & 89 & 2.19 \\
\hline 0.048 & 5.84 & 2.58 & 110 & 2.25 \\
\hline 0.058 & 5.87 & 3.26 & 74 & 2.19 \\
\hline 0.078 & 6.30 & 2.71 & 33 & 1.93 \\
\hline
\end{tabular}

SL/M: seed latex to monomer ratio; Dp: mean particle diameter; CV: coefficient of variation for size distribution; SSA: specific surface area.

changing seed latex/monomer ratio are given in Figure 2. The properties of poly(TMSPM-co-EDMA) microparticles are given in Table 1.

As shown in Figure 2 and Table 1, the particles were produced in monodisperse form. The fact that less than 5 $\%$ of the coefficient of variation also confirmed monodispersity. It is clear from Figure 2 that the surface has a sponge-like porous structure. No significant change in particle diameter was observed when the seed latex / monomer ratio was increased. The highest surface area was obtained with the seed latex/monomer ratio of $0.048 \mathrm{~g} / \mathrm{mL}$. The average size and the coefficient of variation for poly(TMSPM-co-EDMA) microparticles synthesized with seed latex/monomer ratio as $0.048 \mathrm{~g} /$ $\mathrm{mL}$ were calculated as $5.84 \mu \mathrm{m}$ and $2.58 \%$, respectively. The Si contents of particles were determined as $2.25 \%$ wt by EDX analysis.

SEM photographs showing the size distribution and morphology of monodisperse porous poly(TMSPMCo-EDMA) particles synthesized by varying $\mathrm{Cyc}-\mathrm{OH}$ / DBP ratios are given in Figure 3. The SEM photographs clearly showed that the macroporous fraction disappeared and the mesopores became more dominant when
DBP as a microporogen was increased in the porogen mixture. Average size diameter, coefficient of variation, surface area values and Si contents are given in Table 2 .

When $\mathrm{Cyc}-\mathrm{OH} / \mathrm{DBP}$ ratio was increased, an increase in particle diameter was observed. The $\mathrm{Cyc}-\mathrm{OH} / \mathrm{DBP}$ ratios markedly affected the specific surface area. The total amount of porogen is kept constant, the specific area is $110 \mathrm{~m} 2 / \mathrm{g}$ while Cyc-OH / DBP ratio is 1.15 / 1.35 . It decreases to 17.5 and $25 \mathrm{~m}^{2} / \mathrm{g}$, while the $\mathrm{Cyc}-\mathrm{OH} / \mathrm{DBP}$ ratio is $0.7 / 1.8$ and $2.1 / 0.4$ respectively. On the other hand, Si content was $1.63 \%$ and $1.52 \%$, while $\mathrm{Cyc}-\mathrm{OH} /$ DBP ratios for poly (TMSPM-co-EDMA) particles were $0.7 / 1.8$ and $2.1 / 0.4$, respectively. Based on the characterization studies performed, the particles synthesized with Cyc-OH / DBP ratio of $1.15 / 1.35(\mathrm{~mL} / \mathrm{mL})$ and the seed latex/monomer ratio of $0.048(\mathrm{~g} / \mathrm{mL})$ were selected for use in chromatographic analyzes because of their high specific surface area and Si content.

\section{Chromatography}

The back pressure-flow rate plot obtained for GSH attached TMSPM@poly (TMSPM-co-EDMA) microparticles is given in Figure 4. As seen here, the back pressure
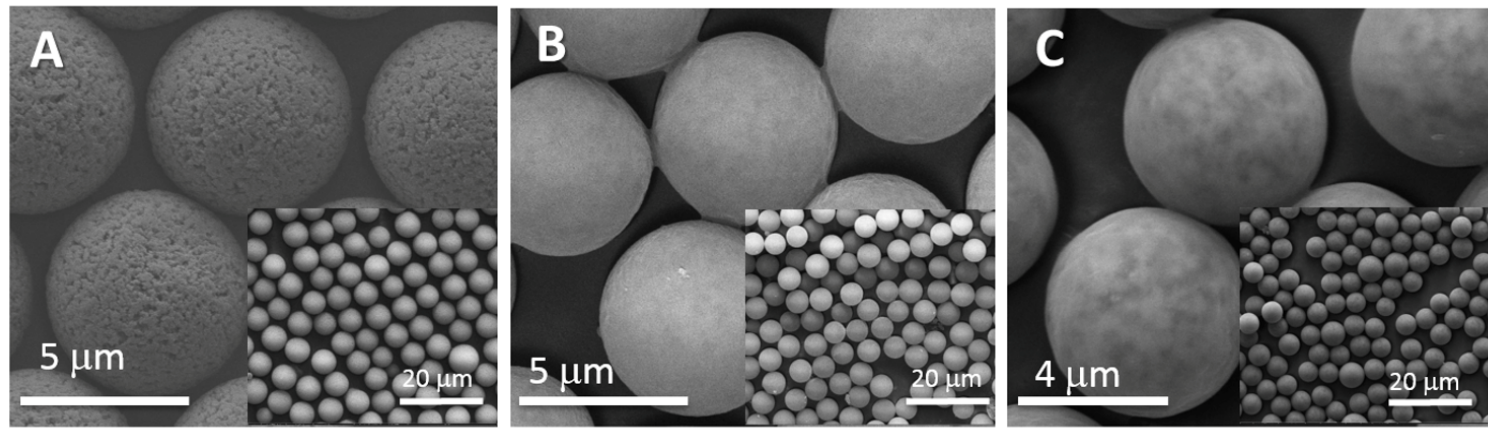

Figure 3. The SEM photographs showing size distribution and surface morphology of monodisperse porous poly(TMSPM-CO-EDMA) microparticles synthesized with different $\mathrm{Cyc}-\mathrm{OH}$ /DBP ratio A) 2.10/0.40, B) 1.15/1.35, C) 0.70/1.80. 
Table 2. The properties of poly(TMSPM-co-EDMA) particles synthesized with different Cyc-OH /DBP ratio.

\begin{tabular}{ccccc}
\hline $\mathrm{SL} / \mathrm{M}(\mathrm{g} / \mathrm{mL})$ & $\mathrm{Dp}(\mu \mathrm{m})$ & $\mathrm{CV}(\%)$ & $\mathrm{SSA}\left(\mathrm{m}^{2} / \mathrm{g}\right)$ & Si content $(\% \mathrm{wt})$ \\
\hline $2.10 / 0.40$ & 5.97 & 3.20 & 25 & 1.52 \\
\hline $1.15 / 1.35$ & 5.84 & 2.58 & 110 & 2.25 \\
\hline $0.70 / 1.80$ & 5.09 & 3.46 & 17.5 & 1.63 \\
\hline
\end{tabular}

Dp: mean particle diameter; CV:coefficient of variation for size distribution; SSA:specific surface area.

increased linearly with the increasing flow rate. The permeability of the microcolumn was calculated as 3.4 $\times 10^{-14} \mathrm{~m}^{2}$.

GSH attached-TMSPM@poly(TMSPM-co-EDMA) microparticles were tested for the separation of polar analytes in HILIC mode to determine their chromatographic performance. For this purpose, the retention behaviors of polar analytes along the column was investigated under different mobile phase conditions. The separation of text mixtures including uracil, adenine, inosine and cytidine was investigated by changing the volume percentage of acetonitrile in the mobile phase from $90 \%$ to $95 \% \mathrm{v} / \mathrm{v}$. The retention factors of the analytes dec- reased as the volume percentage of acetonitrile decreased (Figure 5). This tendency which is consistent with the characteristic behavior of HILIC indicates that GSH attached TMSPM@poly(TMSPM-co-EDMA) microparticles are suitable as a stationary phase in HILIC mode.

Chromatographic separations were performed at different $\mathrm{pH}$ values $(3,7$ and 8$)$ to investigate the effect of $\mathrm{pH}$ on the separation of nucleosides. From Figure 6, it was seen that $\mathrm{pH}$ had no significant effect on the separation of nucleosides.

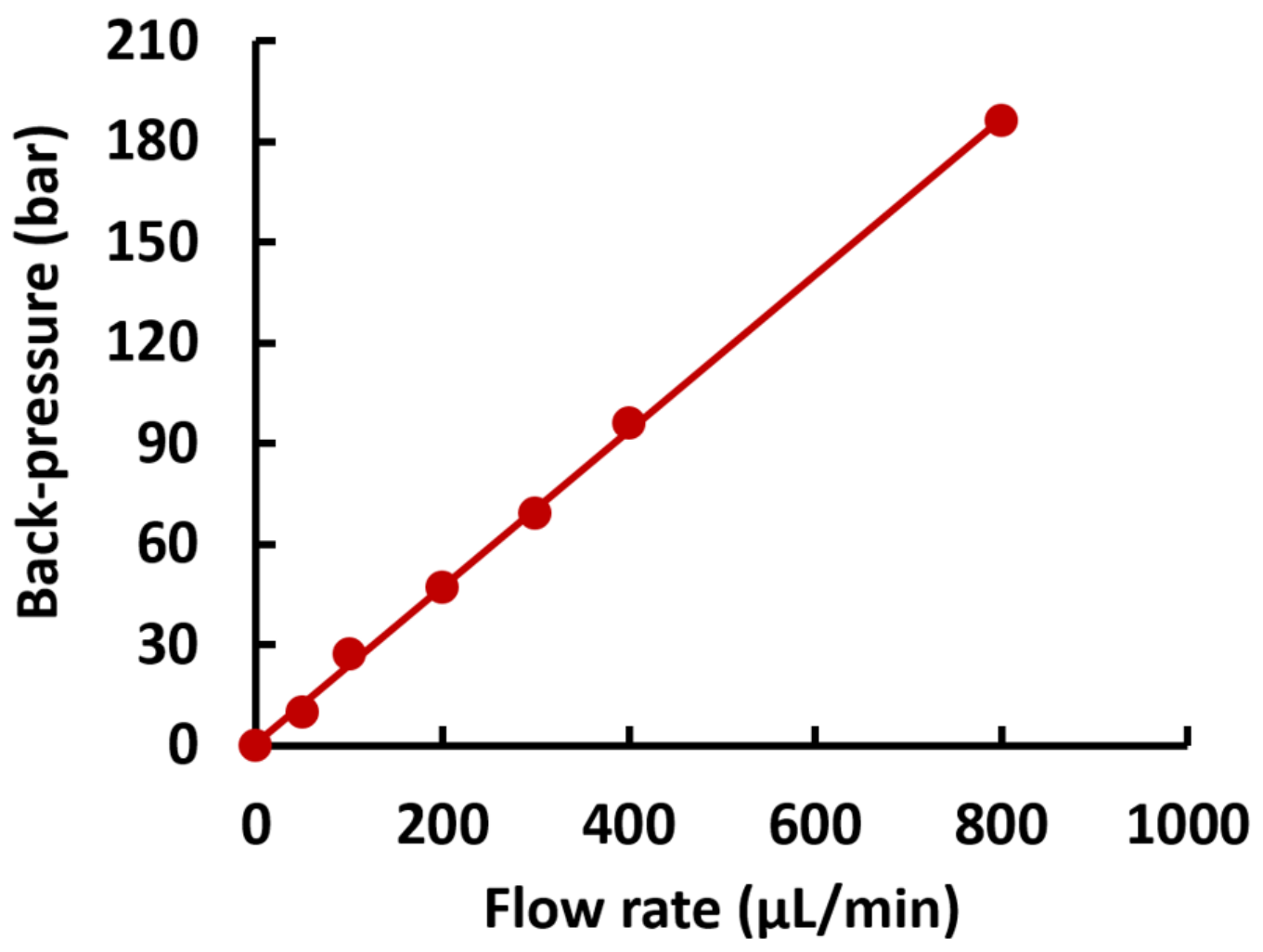

Figure 4. The variation of back pressure of column with the flow rate of mobile phase. Mobile phase: Acetonitrile / water $(93 / 7 \mathrm{~mL} / \mathrm{mL})$. 


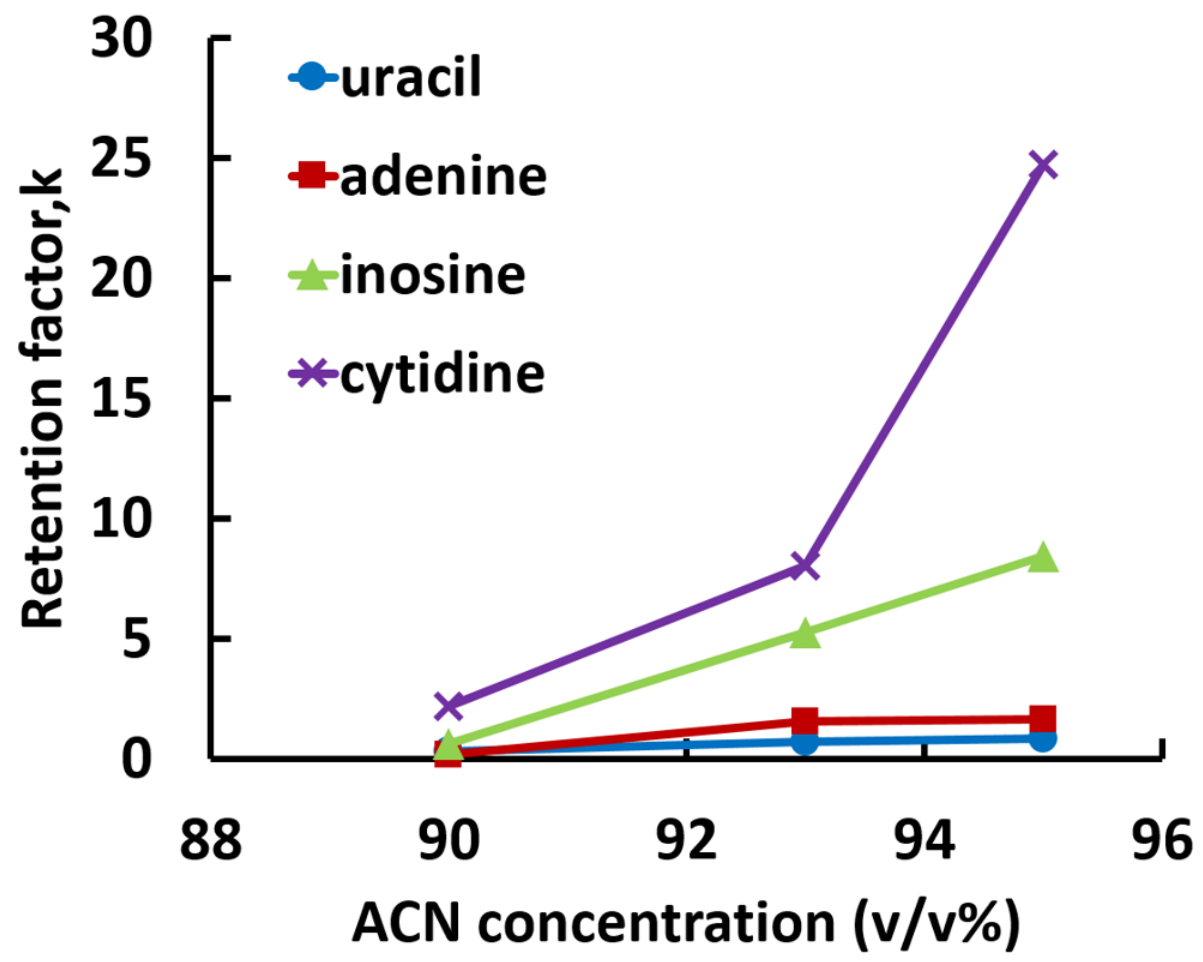

Figure 5. Effect of ACN concentration on the retention of nucleosides on the GSH attached-TMSPM@poly(TMSPM-co-EDMA) microparticles.

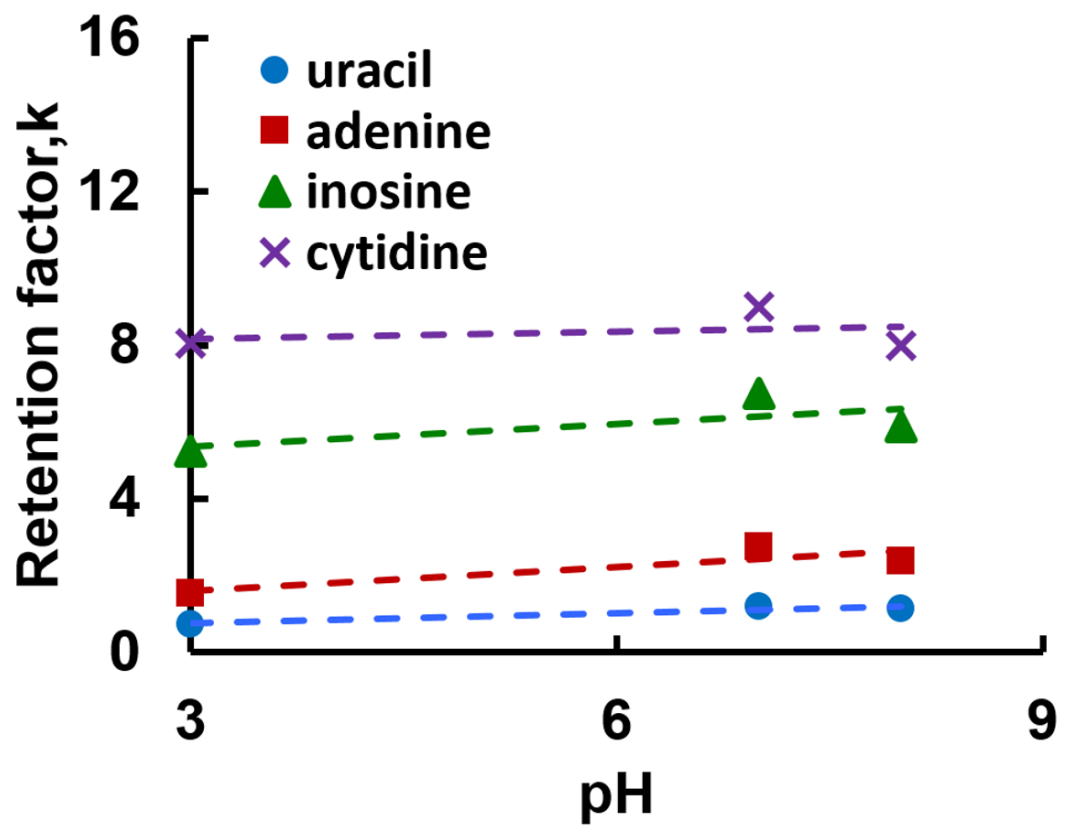

Figure 6. Effect of pH on the retention of nucleosides on the GSH attached-TMSPM@poly (TMSPM-co-EDMA) microparticles. 

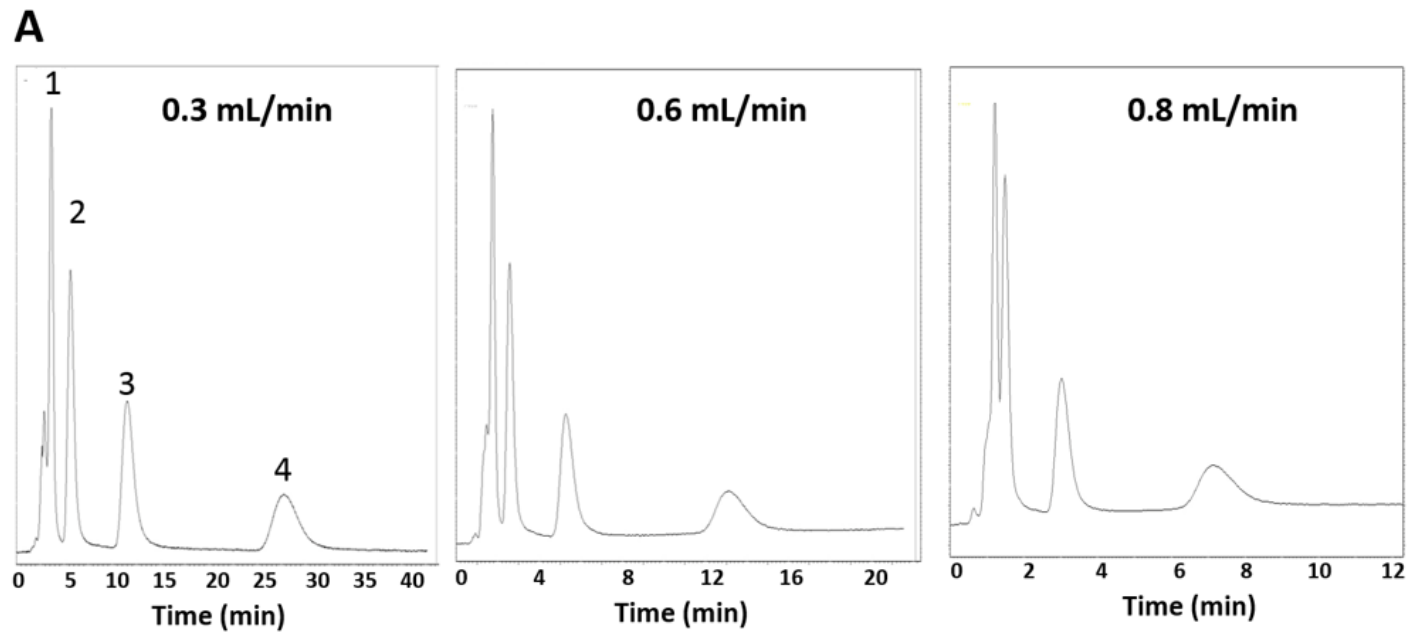

B

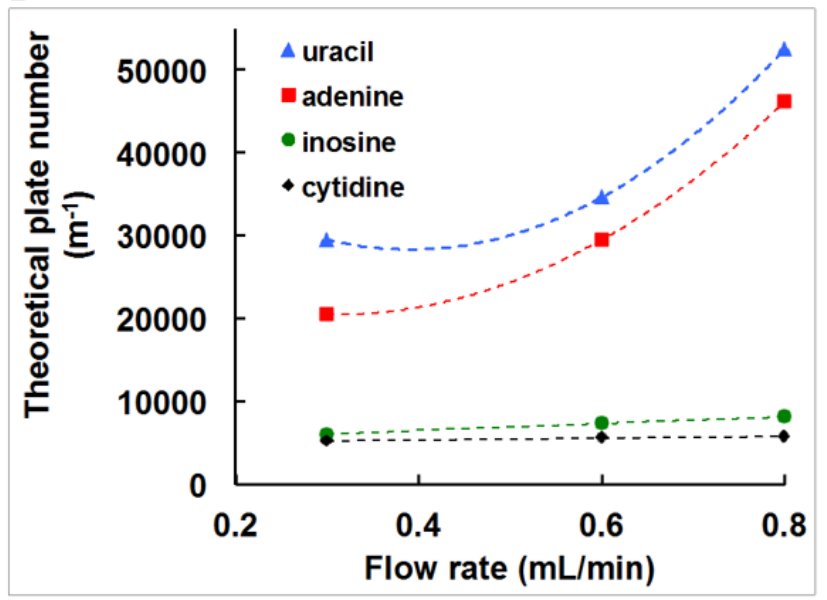

Figure 7. A) The chromatograms obtained with different flow rate for the isocratic separation of nucleosides on GSH attached TMSPM@ poly (TMSPM-co-EDMA) column. Order of elution: 1. uracil, 2. adenine, 3. inosine, 4. cytidine. Chromatographic conditions: Column: $2 \mathrm{~mm}$ i.d. $\times 300 \mathrm{~mm}$ in length, ACN/water ratio: 93/7, pH: 3.0, detection: DAD at $214 \mathrm{~nm}$. Flow rates ( $\mu \mathrm{L} / \mathrm{min}$ ) were given on each chromatogram. B) Variation of theoretical plate number with the flow rate in the separation of nucleosides in the column packed with GSH attached TMSPM@poly (TMSPM-co-EDMA) microparticles. Chromatographic conditions are given in A.

The chromatograms obtained from the separation of the test mixture with different flow rates are given in Figure 7A. The peak resolutions calculated from the chromatograms are given in Table 3. As seen in the chromatograms and from the calculated peak resolutions, the polar analytes were satisfactorily separated with the flow rates up to $0.6 \mathrm{~mL} / \mathrm{min}$. The chromatographic separation was achieved less than 15 minutes with the highest flow rate $(0.6 \mathrm{~mL} / \mathrm{min})$. The theoretical plate numbers ranging between 30000 and 54000 plates $/ \mathrm{m}$ were observed when uracil was selected as analyte (Figure 7B). Based on these results, one can conclude that HILIC columns synthesized by thiol-ene chemistry exhibited good separation performance with high efficiency.
In order to test the stability of the developed column, Run to run" and "Day to day" repeatability tests were performed. "Run to run" and "Day to day" repeatability values smaller than 1.15 and $3.85 \%$ (RSD), respectively, showed that good precision and stability could be achieved with the GSH attached-TMSPM@poly(TMSPM-coEDMA) column under HILIC conditions.

\section{Conclusion}

The starting material selected in this study allowed direct attachment of zwitterionic ligands onto the support material using thiol-ene chemistry. Monodisperseporous poly(TMSPM-co-EDMA) microspheres with the size and porous properties appropriate for use in microbore chromatography were obtained. Glutathione was 
Table 3. The effect of flow rate on the peak resolution obtained in the separation of nucleosides on GSH attached TMSPM@poly (TMSPM-co-EDMA) column.

\begin{tabular}{|c|c|c|c|}
\hline Flow rate ( L/min) & $\mathrm{R}_{21}$ & $\mathrm{R}_{32}$ & $\mathrm{R}_{43}$ \\
\hline 0.2 & 3.05 & 4.02 & 5.06 \\
\hline 0.3 & 2.17 & 3.49 & 4.89 \\
\hline 0.6 & 2.02 & 3.35 & 4.17 \\
\hline 0.8 & 0.83 & 2.91 & 3.02 \\
\hline
\end{tabular}

successfully attached onto the poly(TMSPM-Co-EDMA) microspheres via thiol-ene chemistry. Glutathione attachedTMSPM@poly(TMSPM-co-EDMA) microspheres were successfully used as a stationary phase for the HILIC separation of nucleosides in isocratic mode. GSH attached-TMSPM@poly(TMSPM-co-EDMA) column had a high separation performance with a column efficiency of 54000 plates/m for uracil under HILIC conditions. The successful results obtained in the separation of nucleosides suggest that the developed column can be a promising tool for the analysis of polar analytes.

\section{Acknowledgments}

This research is supported by Hacettepe University Scientific Research Projects Coordination Unit under contract numbered as FHD-2016-8480. The author also thanks Prof. Dr. Ali TUNCEL for his valuable help to use his laboratory facilities.

\section{References}

1. A.J. Alpert, Hydrophilic-Interaction chromatography for the separation of peptides, nucleic-Acids and other polar compounds, J. Chromatogr., 499 (1990) 177-196.

2. T. Ikegami, K. Tomomatsu, H. Takubo, K. Horie, N. Tanaka, Separation efficiencies in hydrophilic interaction chromatography, J. Chromatogr. A, 1184 (2008) 474-503.

3. Y. Guo, S. Gaiki, Retention behavior of small polar compounds on polar stationary phases in hydrophilic interaction chromatography, J. Chromatogr. A, 1074 (2005) 71-80

4. A.R. Oyler, B.L. Armstrong, J.Y. Cha, M.X. Zhou, Q. Yang, R.I. Robinson, R. Dunphy, D.J. Burinsky, Hydrophilic-Interaction Chromatography on Amino-Silica Phases Complements Reversed-Phase High Performance Liquid Chromatography and Capillary Electrophoresis for Peptide Analysis, J. Chromatogr. A., 724 (1996) 378-383.

5. T.J. Yoshida, Peptide separation by Hydrophilic-Interaction Chromatography: a review, Biochem Biophys Meth., 60 (2004) 265-280.

6. Z.G. Hao, C. Lu, B.M. Xiao, N.D. Wenig, B. Parker, M. Knapp, C. Ho, Separation of amino acids, peptides and corresponding Amadori compounds on a silica column at elevated temperature, J. Chromatogr. A., 1147 (2007) 165-171.
7. T. Ikegami, K. Tomomatsu, H. Takubo, K. Horie, N. Tanaka, Separation efficiencies in hydrophilic interaction chromatography, J. Chromatogr. A., 1184 (2008) 474-503.

8. S. Cubbon, T. Bradbury, J. Wilson, J. Thomas-Oates, Hydrophilic interaction chromatography for mass spectrometric metabonomic studies of urine, Anal Chem., 79 (2007) 8911-8918.

9. B. Buszewski, S. Noga, Hydrophilic interaction liquid chromatography (HILIC)-a powerful separation technique, Anal. Bioanal. Chem., 402 (2012) 231-247.

10. B. Alberts, A. Johnson, J. Lewis, M. Raff, K. Roberts, P. Walter, Molecular biology of the cell, New York: Garland Science, 2002.

11. N. Kochanowski, F. Blanchard, R. Cacan, F. Chirat, E. Guedon, A. Marc, J.L. Goergen, Intracellular nucleotide and nucleotide sugar contents of cultured $\mathrm{CHO}$ cells determined by a fast, sensitive, and high-resolution ion-pair RP-HPLC, Anal. Biochem., 348 (2006) 243-251.

12. P. Yeung, L. Ding, W.L. Casley, HPLC assay with UV detection for determination of RBC purine nucleotide concentrations and application for biomarker study in vivo, J. Pharm. Biomed. Anal., 47 (2008) 377-382.

13. X. Lv, W. Tan, Y. Chen, Y. Chen, M. Ma, B. Chen, S. Yao, Facile "one-pot" synthesis of poly(methacrylic acid)-based hybridmonolith via thiol-ene click reaction for hydrophilic interactionchromatography, J. Chromatogr. A., 1454 (2016) 49-57.

14. J. Zeng, S. Liu, M. Wang, S. Yao, Y. Chen, The synthesis of weak acidic type hybrid monolith via thiol-ene click chemistry and its application in hydrophilic interaction chromatography, Electrophoresis, 38 (2017) 1325-1333

15. J. Bai, Z. Liu, H. Wang, X. You, J. Ou, Y. Shen, M. Ye, Preparation and characterization of hydrophilic hybrid monoliths viathiol-ene click polymerization and their applications inchromatographic analysis and glycopeptides enrichment, J. Chromatogr. A., 1498 (2017) 37-45.

16. A. Shen, Z. Guo, L. Yu, L. Caoa, X. Liang, A novel zwitterionic HILIC stationary phase based on "thiol-ene" click chemistry between cysteine and vinyl silica, Chem. Commun., 47 (2011) 4550-4552.

17. W. Shao, J. Liu, Y. Liang, K. Yang, Y. Min, X. Zhang, Z. Liang, L. Zhang, Y. Zhang, "Thiol-ene" grafting of silica particles with three-dimensional branched copolymer for HILIC/cationexchange chromatographic separation and $\mathrm{N}$-glycopeptide enrichment, Anal. Bioanal. Chem., 410 (2018) 1019-1027.

18. A. Shen, Z. Guo, X. Cai, X. Xue, X. Liang, Preparation and chromatographic evaluation of a cysteine-bonded zwitterionic hydrophilic interaction liquid chromatography stationary phase, J. Chromatogr. A., 1228 (2012) 175-182. 
19. C.E. Hoyle, C. Bowman, Thiol-ene click chemistry, Angew. Chem. Int. Ed., 49 (2010) 1540-1573.

20. C.J. Huang, L.C. Wang, C.Y. Liu, A.S. Chiang, Y.C. Chang, Natural zwitterionic organosulfurs as surface ligands for antifouling and responsive properties, Biointerphases, 9 (2014) 029010.

21. Z. Lin, X. Tan, R. Yu, J. Lin, X. Yin, L. Zhang, H. Yang, One-pot preparation of glutathione-silica hybrid monolith formixedmode capillary liquid chromatography based on "thiolene"click chemistry, J. Chromatogr. A., 1355 (2014) 228-237.

22. A. Shen, X. Li, X. Dong, J. Wei, Z. Guo, X. Liang, Glutathione-based zwitterionic stationary phase for hydrophilicinteraction/cation-exchange mixed-mode chromatography, J Chromatogr. A., 1314 (2013) 63-69.

23. L. Qiao, A. Dou, X. Shi, H. Li, Y. Shan, X. Lu, G. Xu, Development and evaluation of new imidazolium-based zwitterionic stationary phases for hydrophilic interaction chromatography, J. Chromatogr. A., 1286 (2013) 137-45.

24. X.T. Peng, T. Liu, S.X. Ji, Y.Q. Feng, Preparation of a novel carboxyl stationary phase by "thiol-ene" click chemistry for hydrophilic interaction chromatography, J. Sep. Sci., 16 (2013) 2571-2577.

25. X. Ren, K. Zhang, D. Gao, Q. Fu, J. Zeng, D. Zhou, L. Wang, Z. Xia, Mixed-mode liquid chromatography with a stationary phase co-functionalized with ionic liquid embedded C18 and an aryl sulfonate group, J. Chromatogr. A., 1564 (2018) 137-144.
26. D. Yang, D. P. Yu, X.F. Dong, A.J. Shen, G.W. Jin, Z.M. Guo, J.Y. Yan, M.Y. Liu, X.M. Liang, Chemically Bonded Polyacrylamide via Thiol-Ene Click Chemistry as Separation Materials for Hydrophilic Interaction Liquid Chromatography, Chinese J. Anal. Chem., 43 (2015) 1439-1444.

27. T. Çamli, M. Hayran, S. Şenel, A. Tuncel, Functional, uniform, and macroporous latex particles: Preparation, electron microscopic characterization, and nonspecific protein adsorption properties, J. Appl. Polym. Sci., 84 (2002) 414429.

28. A. Tuncel, Electron microscopic observation of uniform macroporous particles. II. Effect of DVB concentration, J. Appl. Polym. Sci., 71 (1999) 2291-2302.

29. E. Unsal, S. T. Çamlı, M. Tuncel, S. Şenel, A. Tuncel, Monodisperse-porous particles with different polarities by "modified seeded polymerization" and their use as chromatographic packing in HPLC, React. Funct. Polym., 61 (2004) 353-368.

30. E. Unsal, T. Irmak, E. Durusoy, M. Tuncel, A. Tuncel, Monodisperse porous polymer particles with polyionic ligands for ion exchange separation of proteins, Anal. Chim. Acta, 570 (2006) 240-248.

31. G. Günal, Ç. Kip, S.E. Öğüt, D.D. Usta, E. Şenlik, G. Kibar, A. Tuncel, Human genomic DNA isolation from whole blood using a simple microfluidic system with silica- and polymerbased stationary phases, Mater. Sci. Eng. C Mater. Biol. Appl., 74 (2017) 10-20. 